\title{
The Usage and Perceptions of Mobile Telecommunication Services by Selected South African Students
}

\author{
Omotayo Kayode Abatan \\ University of South Africa
}

\author{
Manoj Maharaj \\ University of KwaZulu-Natal
}

\begin{abstract}
Young people are fascinated by new information and communication technologies. This is evident in the attraction to social networks and new modes of communication offered by mobile telecommunication networks. Beyond communicating with others, new generation mobile phones enable users to perform an assortment of tasks which were hitherto inconceivable. The youth use mobile technology to create and maintain social interactions while also relying on it for educational purposes. This paper, based on empirical research, examines the educational and social uses of mobile telecommunication services by first-year Information Technology (IT) students at the University of KwaZulu-Natal, South Africa. The study provides insight into the usage of mobile telecommunication services for different academic and social activities from students' perceptions. The study identifies some factors that influence the adoption and usage of mobile phones in education. Students' use of mobile telecommunications services is analyzed using the Technology Acceptance Model (TAM) and the theory of planned behaviour.
\end{abstract}

\section{Introduction}

Advances in technology and changes in the social and political spheres have had a great effect on telecommunications [1]. Telecommunications encapsulate voice, video and internet communication services. Modern telecommunication services consist of, but not limited to, voice communication, video streaming, graphics and television services at high speed. Technological advances have enabled telecommunication users to exchange data using cell phones, laptops and other telecommunication devices like Universal Serial Bus (USB) Modems or data cards at affordable rates. The word telecommunication is a combination of two words: tele and communication. The Greek word tele means over a distance. Communication simply means the sharing of information or messages between two or more entities [2]. The addition of the prefix tele to communication gives telecommunication, which simply put, refers to communication over or across distance.

Telecommunication services always improve in their quality of connectivity as technology advances. For instance, wireless transmission (which represents advancement in information sharing) offers many advantages over wire-bound transmission [3]. In a different context, mobile telecommunication providers are deploying new technologies that allow users to replace the conventional landline with mobile telephones.

In the present global age research work in the area of telecommunication is increasing. This study adopts a problem-solution oriented approach to the analysis of first-year IT students' use of mobile telecommunication services at the University of KwaZulu-Natal (UKZN), Durban, South Africa.

Mobile telecommunication service is a technology that has been accepted by people [4]. All users require a level of quality of their mobile telecommunication service at a competitive price. If the service charges are too high, it is easy for users to switch to network providers with lower service charges and quality that they require. This is one major problem in the adoption and usage of mobile telecommunications.

The use of mobile telecommunication services is important to network providers; it keeps them in business. Without good standards of quality and the provision of services that meet users' expectations, network providers will lose users. Services that are provided must not only enable users to meet certain needs but also guarantee affordability on the part of the target market. This assumption holds true for students in South Africa, and elsewhere. This study draws from students' articulation of the use of mobile telecommunications services across mobile telecommunication networks in South Africa. Students' narratives of their use of mobile telecommunication services for academic and social activities foreground the importance of these services in students' lives. 
Therefore, the research questions are broken down into two-folds:

1) What are the perceptions of first-year IT students at UKZN vis-à-vis mobile telecommunication services in Durban?

2) What factors influence the quality of mobile telecommunication services in Durban?

In what follows, this paper discusses the models that serve as the theoretical anchors for the study. It then presents the research method, including the mode of data collection and analysis. Next, the paper gives a brief profile of the telecommunications sector in South Africa. A general discussion of students' use of mobile telecommunications narrows down into the description of the study's findings in respect of first-year IT students at UKZN. The paper then presents the limitation of the study and concludes with an argument for the integration of mobile telecommunication services into teaching and learning.

\section{Theoretical framework}

The theory adopted for the study is the Technology Acceptance Model (TAM). Technology acceptance model is well known and it is related to technology use and acceptance. "TAM is a theoretical model that has been used to explain and predict user's behaviour in information technology" [5].

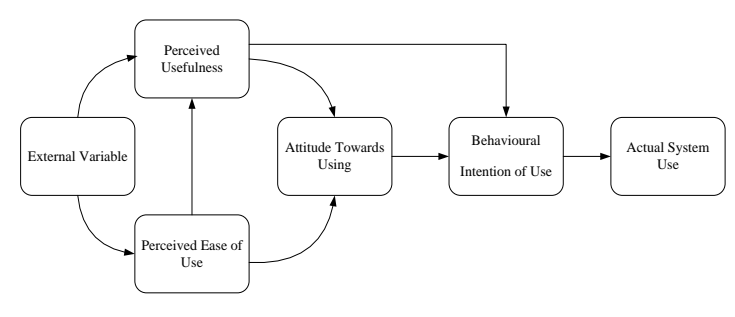

Figure 1. Technology Acceptance Model (TAM)

TAM provides a foundation for identifying the effect of external variables on the internal values, attitudes and the intention to use technology [6]. According to TAM the attitude of users determines the intention to use technology and the intention eventually influences the actual use of such technology [7]. However, Davis and Venkatesh deemphasise the significance of attitude as a determinant of the use of technology but argue that perceived usefulness and perceived ease of use are critical factors that influence the use of technology [7].

Adding to the aforementioned factors, the awareness of the availability of technology is crucial to determining the intention of using the technology and the actual use of the technology. The assumptions of TAM offer some utility to this study. Students' behaviour in the form of their attitudes and intentions, perceived usefulness as well as perceived ease of use of mobile telecommunication services also determine the actual use of the services.

Further backing to the theoretical framework adopted for this paper was from Siragusa and Dixon [8] who stated that the theory of planned behaviour is also used to understand people's intention to engage in a number of activities. Some of the activities were described in this study which includes the use of mobile telecommunication services for academic and social activities. Therefore, the theory of planned behaviour presupposes that intentions to involve and relate with a particular programme is achieved by attitudes towards using information and communication technology, supposed social pressure to do so and by perceived control over the interaction [9].

The conceptual models (TAM and the theory of planned behaviour) are used to interpret the findings of this study. The paper essentially extrapolates the assumptions of TAM. One of such assumptions presupposes that the use of technology is a function of the awareness of the existence and usefulness of such technology by a potential or actual user. In the context of this study, the use of mobile telecommunication services by first-year IT students is dependent on the awareness about the availability of such services.

Students' behaviour in the form of their attitudes and intentions, perceived usefulness as well as perceived ease of use of mobile telecommunication services also determine the actual use of the services. The attitudes and intentions of first-year IT students towards technology in general and mobile telecommunications in particular are reflected in their use of mobile telecommunication services for academic and social activities. The academic activities entail finding new information, information sharing, research and the use of SMS to check examination results. Some of the social activities include keeping in touch with family, keeping in touch with friends, making new friends and using data services for social networking sites i.e., Facebook.

Consequently, there is a possibility of unpacking the preferences of first-year IT students with reference to the acceptance and the usage of mobile telecommunication services through the extrapolation of the assumptions of TAM. Furthermore, the theory of planned behaviour implies that the intention to connect and relate with a programme or application has an effect on the attitudes directed at the usage of mobile telecommunications services by first-year IT students. 


\section{Methodology}

\subsection{Population and sampling techniques}

The data for this paper was generated from research conducted in 2011 amongst first-year IT students at the Westville campus of the University of KwaZulu-Natal. The population of first-year IT students in UKZN was estimated at 945 based on the 2011 student roll. The sample for the study was obtained through simple random technique. Simple random sampling of finite population is described by choosing elements randomly from a population one step at a time and at each step the remaining elements in the population are guaranteed that they have the probability of being selected [10]. Using this logic, a 50\% simple random sample was selected by distribution of 500 questionnaires to the student cohort. A total number of 313 questionnaires were obtained out of the 500 handed out.

Table 1. Description of sample

\begin{tabular}{|c|r|c|c|c|c|}
\hline \multicolumn{6}{|c|}{ Description of Sample - LASU } \\
\hline \multirow{2}{*}{} & Frequency & $\%$ & $\begin{array}{c}\text { Valid } \\
\%\end{array}$ & $\begin{array}{c}\text { Cumulative } \\
\%\end{array}$ \\
\hline \multirow{3}{*}{ Valid } & Male & 129 & 41.2 & 41.0 & 41.3 \\
\cline { 2 - 6 } & Female & 183 & 58.5 & 59.0 & 100.0 \\
\cline { 2 - 6 } & Total & 312 & 99.7 & 100.0 & \\
\hline Missing & System & 1 & 0.3 & & \\
\hline \multicolumn{7}{|c|}{ Total } & 313 & 100.0 & & \\
\hline
\end{tabular}

\subsection{Data collection instrument}

A self-administered questionnaire was designed for the primary data collection procedure. The selfadministered questionnaires consisted of structured, closed format, biographical and rating scale type of questions. The format of the questionnaire elicited information about the relevant issues on the use of mobile telecommunication services amongst firstyear IT students in UKZN. The data and information collected are pre-structured according to the assumed relationship between the concepts of the models used [11]. Data analysis was elaborated using set of statistical techniques for data diagnosis such as data preparations, data descriptions and scale analysis so as to improve the validity and reliability of findings. A descriptive and inferential analysis was used to analyze the collected data. Basic features of the collected data were described and interpreted. A combination of statistical software Statistical package for Social Sciences (SPSS) and Microsoft Excel was used for the data analysis. The findings are presented in a subsequent section of this paper.

\section{Overview of South African telecommunications}

The pedigree of telecommunications services in South Africa is generally traced to the creation of South African Post and Telecommunication (SAPT) [12]. SAPT provided telephone, telegraph and post services, and SAPT lawfully monopolized telecommunication and postal services [13]. Telkom South Africa Limited was incorporated in 1992, replacing SAPT. Telkom was given the undivided power and domination to provide telecommunication services, the power to authorize any other entity to carry out telecommunication services in South Africa [14]. Telkom exclusive power and monopoly came to an end when the second network operator running fixed-line services was introduced in the late 2005 under the name, Neotel. Majority owned by India's Tata Communications, Neotel offers telephone and data services with Code Division Multiple Access (CDMA) technology.

In a period of 10 years between 1996 and 2006, fixed line telephone had an estimated number of subscribers from 3.919 million to 4.708 million and mobile telephone subscribers increased from 1 million to 19 million in the South African population estimated to be between 44 and 47 million [15]. From 2006 to 2010, the estimated number of mobile telecommunication subscribers escalated to 29 million (i.e., 10 million subscribers in 4 years). Today, the country's cellular companies provide mobile services to over 46.4 million subscribers [16]. South Africa has four licensed mobile operators; MTN, Vodacom (majority owned by UK's Vodaphone), Cell C (75\% owned by Saudi Oger, an international telecommunication holdings firm) and Virgin Mobile that is a Mobile Virtual Network Operator (MVNO). MVNOs are network operators that operates in partnership with an existing mobile company i.e., Mobile Network Operator (MNO). MVNOs may operate without owning a bandwidth license, the MVNOs use the infrastructures of the existing mobile company and pay MNO a fee for the use of their spectrum [17]. Virgin Mobile is in partnership with Cell C. There is a new entrant called 8ta subsidiary of Telkom South Africa. 8ta was not operational as at when the field work for this study was conducted.

\section{Mobile telecommunications' challenges in South Africa}

South Africa once faced restructuring process in its telecommunication sector and policies that requires putting an end to many questions as regards the boundaries between domination and competitive telecommunication services, tariffs adjustment and many more [13]. Even as the growing 
telecommunication market is creating opportunities for new growth in South African mobile telecommunication market and beyond, the also changing democracy posed regulations to aid the progressive goals of socioeconomic and racial changes on all functional companies in the South Africa [18]. Business expansions of post-Apartheid South Africa influence the expansion of foreign multi-national companies (MNC) in Africa and learning from the renewed economic involvement. Another challenge that the multi-national companies face is the Broad-based black economic empowerment (BBBEE) strategy [18]. The term 'black' in black economic empowerment refers to non-white population. Hence, the South African government and African National Congress (ANC: ruling South African political party) indicated a clear preference for the black African populations [19]. However, South Africa's telecommunication sector has been one of the several sectors where monopoly enterprise has been cut loose or privatized from the direct ministerial control with different level of competition [13].

\section{Findings}

\subsection{Duration of subscription to mobile telecommunication network - UKZN}

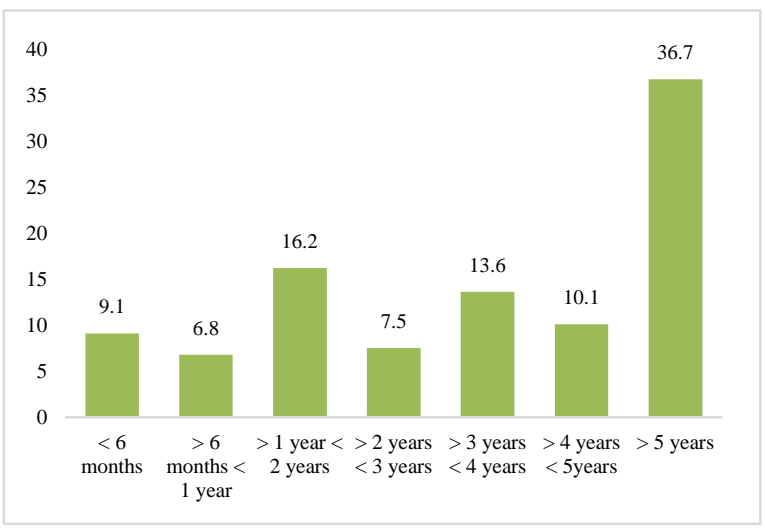

Figure 2. Distribution of mobile telecommunication services

To help in determining the experiences of firstyear IT students in UKZN vis-à-vis their use of mobile telecommunication services, it was necessary to find out the number of years they have been subscribed to their network provider. As shown in figure $2,36.7 \%$ had subscribed to their preferred mobile telecommunication network for more than 5 years. $16.2 \%$ had subscribed for more than 1 year but less than 2 years, $13.6 \%$ for more than 3 years but less than 4 years, $10.1 \%$ for more than 4 years but less than 5 years. Subscribers who had been on their network for more than 2 years but less than 3 years constituted 7.5\%.Participants who had been on their network for more than 6 months but less than 1 year made up $6.8 \%$. The percentage of participants who subscribed to the mobile telecommunication network less than 6 months at the time of the study was $9.1 \%$.

\subsection{Students' perceptions of mobile telecommunication services - UKZN}

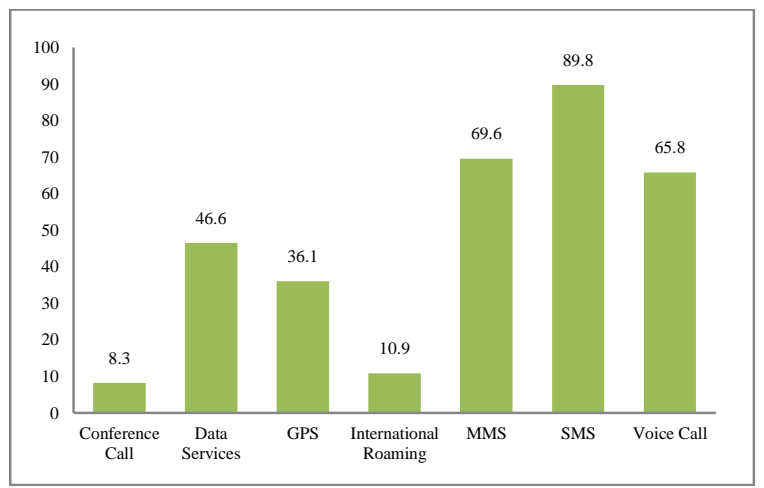

Figure 3. Distribution of mobile telecommunication services

Mobile telecommunication network operators offer a range of services through which students could satisfy their academic and social needs. Participants were asked to indicate the mobile telecommunication services that they use. Figure 3 above shows the number and corresponding percentage of participants who use each service. The use of each service is measured in relation to all 313 participants at UKZN. An overwhelming majority of students $(89.8 \%)$ use SMS, followed by $69.6 \%$ who use MMS. Voice call is used by $65.8 \%$ of participants while $46.6 \%$ use data services. $36.1 \%$ and $10.9 \%$ of students use GPS services and International roaming respectively. 26 students, with the lowest percentage of $8.3 \%$ use conference call.

\section{i. Academic activities}

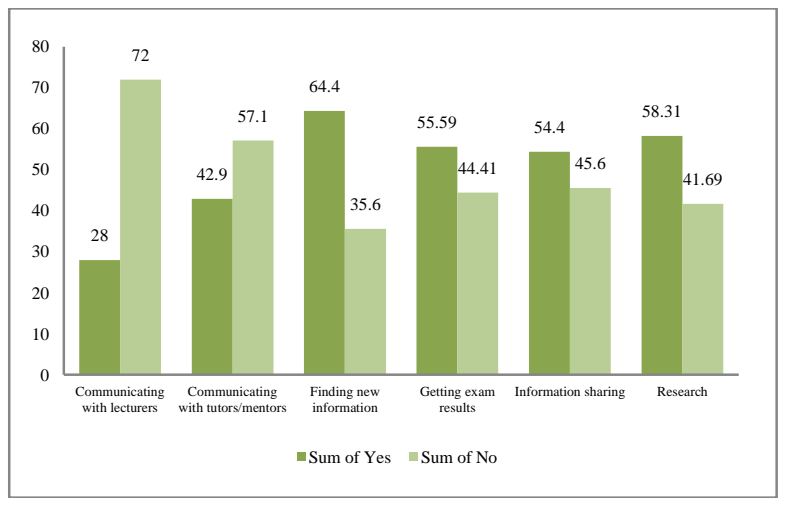

Figure 4. Academic activities 
UKZN first-year IT students were asked to identify the academic activities that they use mobile telecommunication services for and to subsequently identify the frequency at which they use the services in order to enhance their academic agendas. Figure 4 shows the different academic activities that participants use mobile telecommunication services for. As the figure above shows, $64.4 \%$ of participants from UKZN use mobile telecommunication services for the purpose of finding new information. Finding new information is the greatest attraction that mobile telecommunication services have for UKZN participants. The second highest attraction that mobile telecommunication services have is for research as $58.31 \%$ of participants use mobile telecommunication services for this purpose. According to $55.59 \%$ of participants, mobile telecommunication services enabled them to obtain their exam results. The use of mobile telecommunication services for academic activities such as communicating with tutors/mentors (42.9\%) as well as communicating with lecturers (28\%) ranked lowest amongst UKZN participants. The reason for this is not difficult to fathom, given that tutors and lecturers in particular do not generally provide their cell phone numbers to students. The fact that students use mobile telecommunication services for research, finding new information, sharing information and obtaining exam results is significant in that these are important academic activities especially for students in IT-related disciplines.

The importance of the use of mobile telecommunication services for academic activities from the perspective of participants is reflected in this section, which describes the frequency of the use of mobile telecommunication services for academic purposes. The highest number of participants (37.9\%) use mobile telecommunication services for academic purposes every day. Furthermore, in terms of frequency $18.6 \%$ of participants use mobile telecommunication services for academic activities every week. Mobile telecommunication services are used for academic purposes once in every two weeks by $7.8 \%$ of participants. About a quarter of participants that is $26.5 \%$ rarely use mobile telecommunication services for academic purposes while $9.2 \%$ never use mobile telecommunication services for their academic activities. Having said that, more than half of the participants (taking into consideration those in the everyday and every week categories) use mobile telecommunication services regularly for their academic work. Students' articulation of the various uses of mobile telecommunication services for academic activities highlights the potential and actual contributions of mobile technology towards enhancing the processes of knowledge creation and transfer.

\section{ii. Social activities}

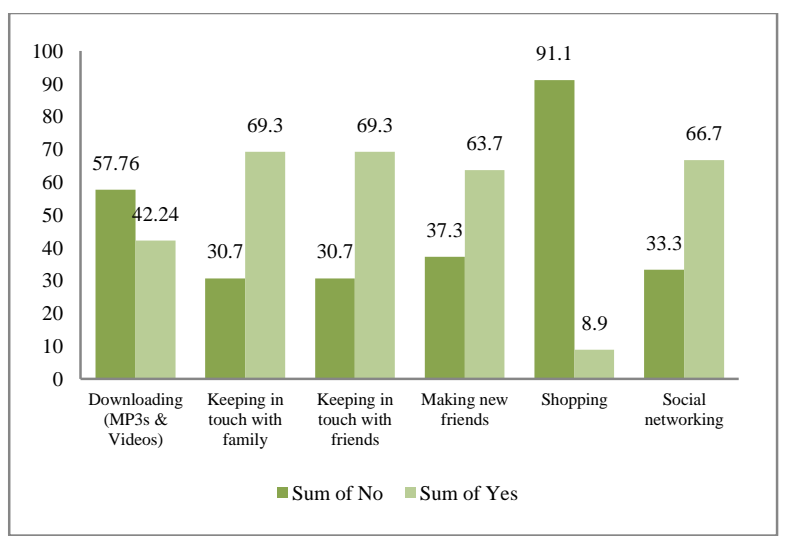

Figure 5. Social activities

UKZN participants were asked to indicate the social activities that they use mobile telecommunications for. Figure 5 depict the social activities for which students use or do not use mobile telecommunication services. While $63.7 \%$ of participants make new friends through the use of mobile telecommunications, the foremost social activities that participants use mobile telecommunications for is keeping in touch with family and friends. The percentage of participants at $69.3 \%$ is the same with reference to both social activities namely keeping in touch with family and keeping in touch with friends. The second significant social activity is indicated by $66.7 \%$ of participants as social networking. The high percentage of participants in this category suggests that mobile telecommunications as a tool for social networking may serve the purpose of keeping in touch with family and friends. Mobile telecommunications also serve the purpose of entertainment, given that $42.24 \%$ of participants use mobile telecommunications to download $\mathrm{Mp} 3 \mathrm{~s}$ and videos. Only a few participants (8.9\%) use mobile telecommunications for shopping. This is not a curious finding in the sense that participants are students, the majority of whom are dependent on financial support from parents or are funded through scholarships/bursaries. As such they may not be able to engage in business transactions using mobile telecommunication platforms such as eWallet.

The relevance of mobile telecommunications to social interaction is implied in this paragraph which describes the frequency of the use of mobile telecommunication services for social activities. A few participants (3.7\%) never use mobile telecommunications for social activities. A further $15.4 \%$ of students surveyed rarely use mobile telecommunications for social activities. A small group of students representing $3.3 \%$ of participants use mobile telecommunications for social activities 
once in every two weeks. The data shows that $8.7 \%$ of participants use mobile telecommunications for social activities every week. The highest number of participants $(68.9 \%)$ use mobile telecommunication services for social activities every day. This follows logically from the table above in which the highest number of participants uses mobile telecommunications to keep in touch with family and friends. Approximately two-thirds of participants (those in the everyday and every week categories) use mobile telecommunication services regularly for social activities. Therefore, it can be said that there is a sense in which mobile telecommunications contribute to social interaction thus enhancing students' social lives.

\section{Discussion of findings}

The findings of this study are done in the context of the research questions using inferential statistics mainly in the form of cross-tabulation and chi-square test. These analyses enable the understanding of the significance of the variables and their influence on participants' perceptions.

Cost/billing services, Customer care services, Network availability, Network stability, User satisfaction and Voice clarity are the major factors that influences adoption and usage of mobile phones for educational purposes. These factors constitute part of the requirements of any mobile telecommunication networks' quality of service. In order to probe the formation of the factors, participants were asked to identify the level of significance of these factors and it is presented in Table 2.

Table 2. Significance of factors

\begin{tabular}{|l|r|r|r|r|r|}
\hline Factors & \multicolumn{5}{|c|}{ Level of significance (\% of respondents) } \\
\hline & $\begin{array}{c}\text { Of no } \\
\text { significance }\end{array}$ & $\begin{array}{c}\text { Of little } \\
\text { significance }\end{array}$ & $\begin{array}{c}\text { Of some } \\
\text { significance }\end{array}$ & Significant & $\begin{array}{c}\text { Very } \\
\text { significant }\end{array}$ \\
\hline Cost/Billing Services & 2.1 & 3.4 & 13.1 & 30.2 & 51.2 \\
\hline Customer Care Services & 1.7 & 5.9 & 7.6 & 27.2 & 57.6 \\
\hline Network Availabilty & 2.4 & 2.7 & 7.1 & 17.3 & 70.4 \\
\hline Network Stability & 1.4 & 3.1 & 7.9 & 21 & 66.7 \\
\hline User Satisfaction & 1.7 & 2.4 & 7.2 & 25.3 & 63.4 \\
\hline Voice Clarity & 1.4 & 3.5 & 3.8 & 30.2 & 61.1 \\
\hline
\end{tabular}

Participant's responses shows that each factor identified is very significant in the adoption and usage of mobile phone for educational purposes. Network availability $(70.4 \%)$ is the most significant factor, followed by Network stability $(66.7 \%)$. The availability and stability of mobile telecommunication networks will greatly influence the attitude towards using the technology as well as impact in the behavioral intention to use the technology which will in turn allow the actual usage of the technology amongst participants. The acceptance and the usage of these mobile telecommunication services (drawing from the assumptions of TAM) have influenced participants' intention to use the services. Hence, the understanding of people's intention to engage or relate with these factors is achieved by participant's attitudes towards using information and communication technology through the assumption of the theory of planned behaviour.

\section{Limitations}

A clear limitation in this research is its focus exclusively on first-year IT students at UKZN. This study's findings help to understand the orientations and attitudes of first-year IT students towards an aspect of technology acceptance and use. However, the behavioural patterns and nuances presented in this study may not necessarily apply to students at higher levels of study in the same discipline or in other disciplines within the university.

\section{Conclusion and recommendations}

Although students are using mobile telecommunication services for academic activities, such use is largely self-defined or at the discretion of students. However, the varying academic uses of mobile telecommunication services suggest that mobile telecommunications could serve as an important pedagogic tool. An understanding of the patterns of usage of mobile telecommunication services by students engenders opportunities to explore ways through which mobile technology could be integrated into teaching and learning processes. It is envisaged that the integration of mobile telecommunications into teaching and learning in universities will facilitate studentcentered learning. The integration of mobile telecommunication services lends itself readily to efforts at mainstreaming ICTs into the teaching and learning processes in universities across the world.

The study provides insights into the usage of mobile telecommunication services for different academic and social activities by first-year IT students at UKZN. While first-year IT students may find it expedient, beneficial or relatively easier to use mobile telecommunication services for these purposes, this may not necessarily be the case for students in other disciplines. Further research with respect to students in other disciplines will likely reveal commonalities and divergences in students' use of mobile telecommunication services. These commonalities and divergences could, in turn, stimulate further scholarly inquiry that could engender benefits for students and academics. In addition, mobile telecommunication network operators could gain from such insights as they seek 
to streamline services to meet the needs of users in a changing and increasingly competitive operational environment.

\section{Acknowledgements}

Special acknowledgment goes to Prof. Manoj Maharaj for the supervision of this project conducted at the University of KwaZulu-Natal and Ayo Whetho for technical advice. Portion of this study have been presented at the International Conference on information Society (i-Society)/IEEE UK/RI Computer Chapter, London, UK, November 10-12, 2014.

\section{References}

[1] M. M. Awny, Social Impact of Technology: A perspective of Developing Countries, 13th International Conference on Management of Technology - IAMOT, 2004, pp. 1-7.

[2] T. Dean, Guide to Telecommunications Technology, 2003.

[3] International Telecommunication Union (ITU), The role of ICT in advancing growth in least developed countries: Trends, Challenges and Opportunities, The 4th United Nation Conference for the LDCs (LDC-IV), Geneva, 2011, pp. 1-163.

[4] L. Fuentelsaz, J. P. Maicas, and Y. Polo, The evolution of mobile communications in Europe: The transition from second to third generation. Telecommunication Policy, 2008, pp. 436-449.

[5] S. Y. Park, An Analysis of the Technology Acceptance Model in Understanding University Students' Behavioural Intention to Use e-Learning, Educational Technology \& Society, 2009, pp. 151.

[6] F. D. Davis, R. P. Bagozzi, and P. R. Warshaw, User Acceptance of Computer Technology: A comparison of two theoretical models*, Management Science, 1989, pp. 985 .

[7] M. Bertrand and S. Bouchard, Applying The Technology Acceptance Model to VR with People Who Are Favorable to Its Use. Journal of CyberTherapy and Rehabilitation, 2008, pp. 200-201.

[8] L. Siragusa, and K. C. Dixon, Planned behaviour: Student attitudes towards the use of ICT interactions in higher education. Proceedings ascilite Melbourne, Bently, Sydney: Curtin University of Technology, 2008, pp. 942953.

[9] M. Fishbein, and I. Ajzen, Belief, Attitude, Intention and Behaviour: An introduction to Theory and Research. Philippines: Addison-Wesley Publishing Company, 1975.
[10] D. R. Anderson, D. J. Sweeny, and T. A. Williams, Statistics for Business and Economics, Mason: Thomson Higher Education, 2009.

[11] A. J. Mills, G. Durepos, and E. Weibe, Encyclopedia of Case Study Research, California: Sage Publication Inc., vol 1, 2010.

[12] T. Cohen, Rethinking (Reluctant) Capture: South African Telecommunications and the Impact of Regulation, Journal of African Law, vol. 47, No. 1, 2003 , pp. 65-87.

[13] R. B. Horwitz, The Uneasy Relation between Political and Economic Reform in South Africa: The Case of Telecommunications, African Affairs, vol. 93, No. 372, 1994, pp. 361-385.

[14] M. Zlotnick, Telecommunications Monopoly in South Africa - Some Human Rights Aspects and Options for Future Regulation. Journal of African Law, vol 43, 1999, pp. 214-233.

[15] R. B. Horwitz, and W. Currie, Another instance where privatization trumped liberalization: The politics of telecommunications reform in South Africa - A ten-year retrospective. Telecommunications Policy 31, 2007, pp. 445-462.

[16] InfoSA, Infrastructure, South Africa's telecommunications: Mobile

http://www.southafrica.info/business/economy/infrastructu re/telecoms.htm\#.U7P9EPmSxb4/ (Access date: 13 April, 2014).

[17] L. Cricelli, M. Grimaldi, and N. L. Ghiron, The competition among mobile network operators in the telecommunication supply chain. International Journal of Production Economics, 2011, pp. 131, 22-29.

[18] D. Sánchez, Transnational Telecommunications Capital Expanding From South Africa into Africa: Adapting to African Growth and South African Transformation Demands. African Sociological Review 12, No. 1, 2008, pp. 103-121.

[19] O. C. Iheduru, Black Economic Power and NationBuilding in Post-Apartheid South Africa. The Journal of Modern African Studies, vol. 42, No. 1, 2004, pp. 1-30. 